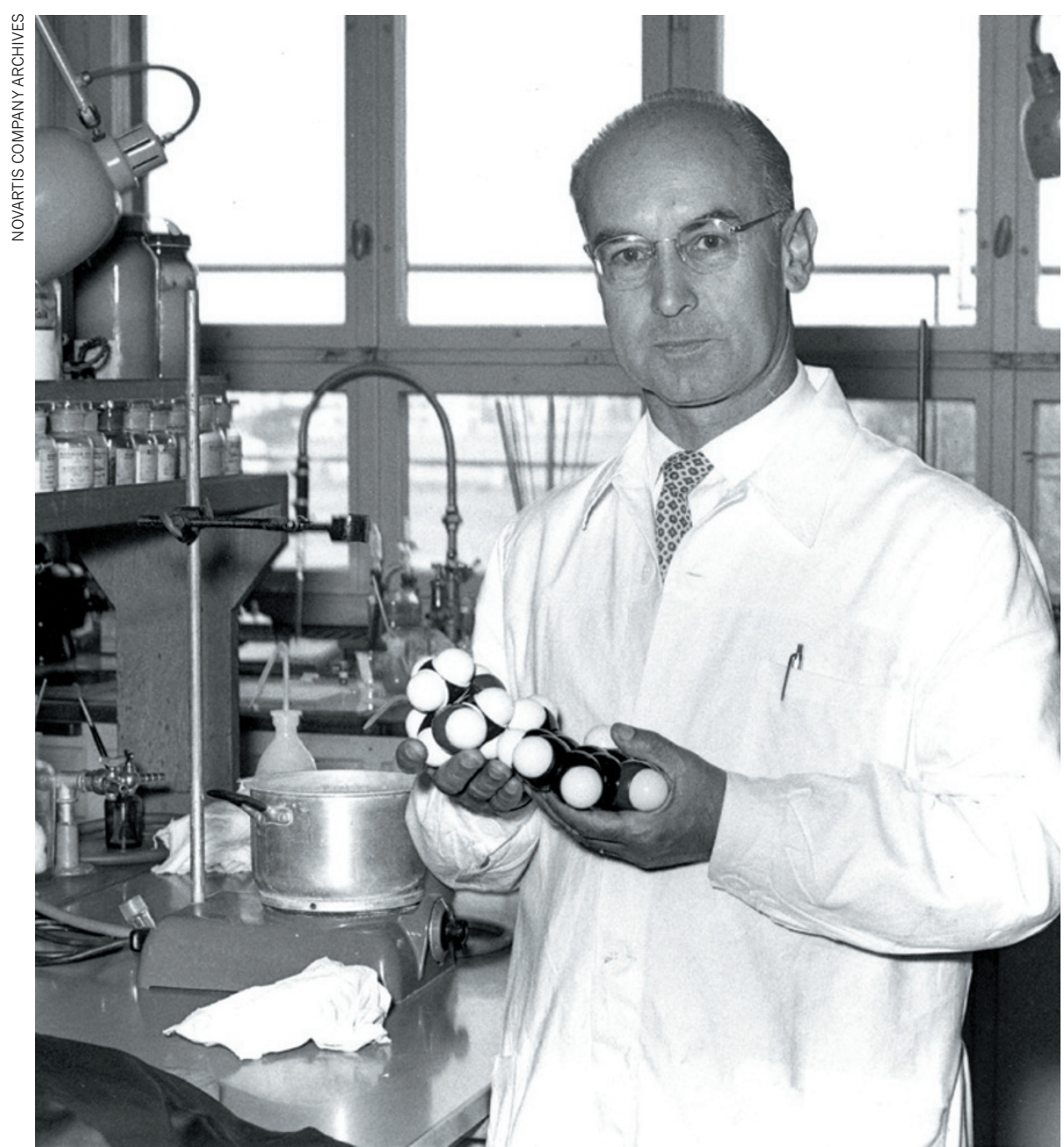

Albert Hofmann holds a model of an LSD molecule.

\title{
DRUG DISCOVERY
}

\section{Synthesized dreams}

\section{Mike Jay contemplates the chemical legacy of Albert Hofmann, who first synthesized LSD 75 years ago.}

\section{A} lbert Hofmann never had a rational explanation for his discovery of the effects of lysergic acid diethylamide (LSD), the 'eureka moment' that changed his life. He first synthesized the hallucinogen in 1938, in the laboratory of pharmaceuticals company Sandoz in Basel, Switzerland, while searching for a cardiovascular stimulant based on ergot, a grain fungus. However, it had shown no particular promise. Five years later, a "peculiar presentiment" prompted him to recreate the molecule, after which he noticed a feeling of slight dizziness and a mild psychoactive effect.

To test whether this had been caused by accidental absorption, three days later Hofmann took what he imagined would be an almost imperceptible 250-microgram dose. By the time he hopped on his bicycle to go home, he found himself taking the ride of his life, entering a hallucinatory landscape of "kaleidoscopic, fantastic images". The modern psychedelic era had begun, although Hofmann had no inkling of the social revolution his discovery would foment.

The classic account of that legendary
LSD: My Problem Child and Insights/ Outlooks

ALBERT HOFMANN (TRANSLATED BY JONATHAN OTT) Oxford University Press: 2013. 248 pp. £24.99

Mystic Chemist: The Life of Albert Hofmann and His Discovery of LSD

DIETER HAGENBACH AND LUCIUS WERTHMÜLLER Synergetic Press: 2013.408 pp. $\$ 49.95$

bicycle trip appears in Hofmann's memoir, LSD: My Problem Child, first published in German in 1979. An English edition from 1980 was withdrawn after publisher McGraw-Hill decided that books about psychedelic drugs should not be on its science list. The memoir is now republished as a new English translation by Jonathan Ott, together with Insights/Outlooks, a collection of Hofmann's philosophical essays that first appeared in German in 1986.

Ott's translation joins another classic, Hofmann's Plants of the Gods (McGrawHill, 1979), the book on the botany and chemistry of plant hallucinogens he coauthored with eminent botanist Richard Schultes. Together with the abundance of valuable photographs and original documents offered in an uncritical biography of Hofmann, Mystic Chemist, these constitute an admirable summation of Hofmann's life and the extraordinary chemical vistas he opened up.

LSD: My Problem Child reminds us that the first generation of LSD pioneers were cultural conservatives. The tone of their investigations is captured in the evocative group photos in Mystic Chemist of industrial chemists in grey flannel suits and with Brylcreemed hair. The drug's biochemistry - now known to act on serotonin receptors - was a mystery to them. However, its powerful effects on perception and cognition (such as making walls seem to ripple and time to stretch out) were found to be similar to those of mescaline, which was isolated from the peyote cactus in 1897. Mescaline had been widely studied by physiologists and psychiatrists, and by writers such as Aldous Huxley, who documented his experiments in The Doors of Perception (Harper \& Brothers, 1954) and later befriended Hofmann.

Among this coterie, psychiatrists such as Humphry Osmond saw LSD as a means of investigating the biochemical basis of schizophrenia. The Central Intelligence Agency (CIA) was also testing it covertly as a brainwashing tool, recklessly administering it to unwitting subjects for as many as 77 successive days. Unlike some of his associates, Hofmann staunchly refused to cooperate with the CIA.

The emerging California counterculture seemed shallow and degenerate to this group. Hofmann's lifelong mentor, author Ernst Jünger, wrote, "I can't agree with Huxley's idea that the masses could be given the opportunity for transcendence." The 
flashpoint came with psychologist Timothy Leary's buccaneering drug experiments that eventually saw him expelled from Harvard University in Cambridge, Massachusetts. In January 1963, Sandoz received an order from Leary for 100 grams of LSD, enough for a million doses. Hofmann referred the request to the US Food and Drug Administration and noted that Leary was courting media publicity "that can only be injurious to the scientific clarification of questions connected with the use of these substances".

Sandoz returned Leary's cheque and in 1966 withdrew LSD from the market, where it had been in steady demand for neurological research and psychiatric use. The vacuum was swiftly filled by underground chemists, who turned out pills and LSD-soaked blotters at strengths that Hofmann considered a massive overdose. But there was no turning the tide.

Hofmann continued to work on the chemistry of ergot alkaloids, on which he became the world's leading authority, and rose to deputy managing director at Sandoz. The next 50 years of his life, as Mystic Chemist doggedly relates, was largely swallowed up by a procession of ethnographers, botanists, psychiatrists, shamans and politicians, seeking his wisdom and showering him with honours.

LSD has been many things to many people, but for Hofmann its core message was that objective reality "is in fact a subjective image". By enhancing idiosyncratic perceptions and ideas, it allows us to create our own reality. In Hofmann's case, it returned him to the radiant childhood vision of nature that had led him to study chemistry in the first place. Among his touchstones were the spirit-infused Naturphilosophie of author Johann Wolfgang von Goethe, the poetry of Johann Christoph Friedrich von Schiller and Rainer Maria Rilke and the alchemical insights of his Swiss compatriot Paracelsus, all enveloped in a mystical Christian revelation that he was "united with the Creation, as a part of the Universe".

After 42 years at Sandoz, Hofmann retired in 1971 to his alpine home on the Swiss-French border, writing of coming full circle to the high meadows of the Jura Mountains, "with the same flowers, and the same view into the distance".

Mike Jay is an author and historian who has written widely on the history of drugs, psychiatry and madness. His books include High Society: Mind-

Altering Drugs in History and Culture, which accompanied the High Society exhibition he co-curated at the Wellcome Collection, London.

e-mail:mail@mikejay.net

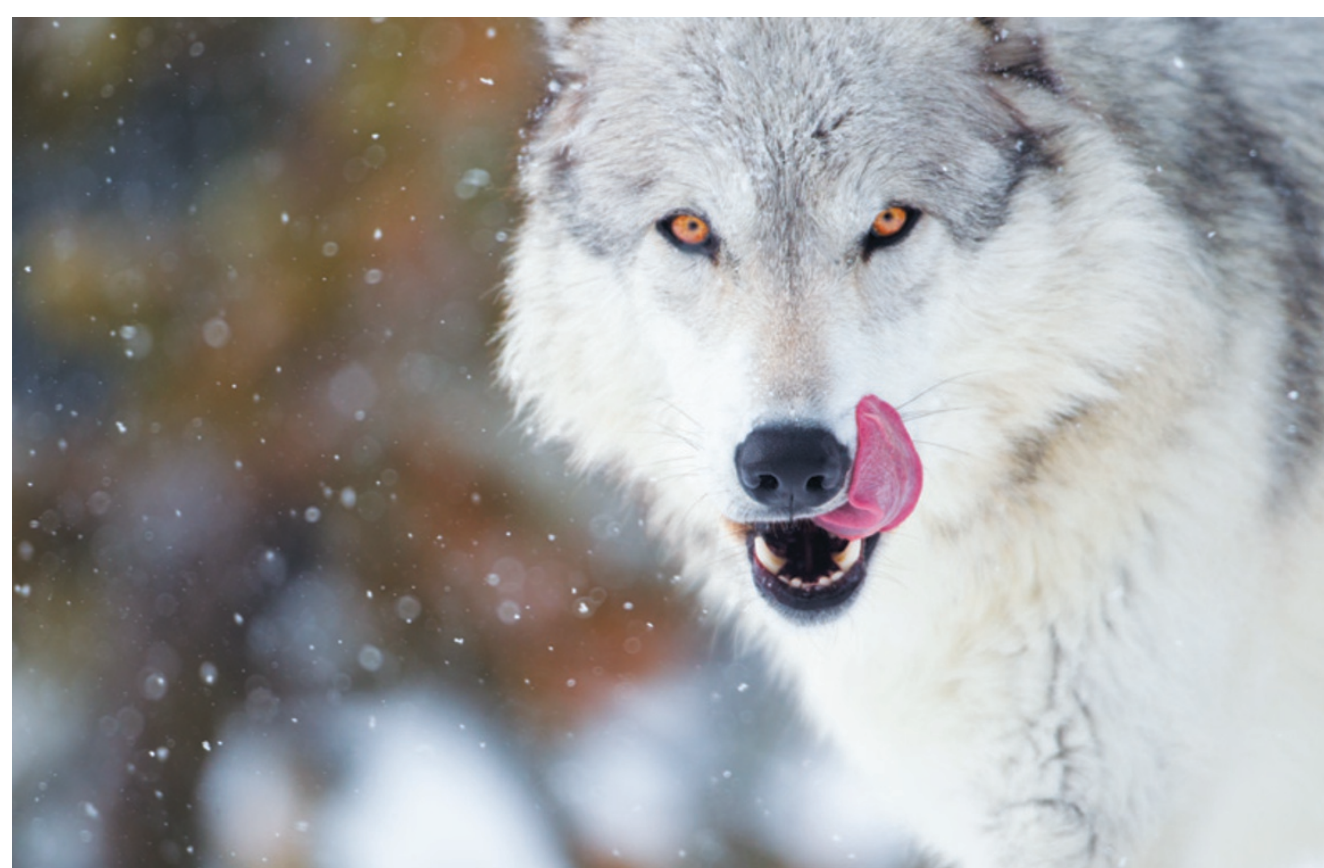

Wolves are among the species that people are seeking to restore to their former habitats.

\section{ECOLOGY}

Into the (re)wild

Shahid Naeem examines the seductive concept of repopulating habitats with locally extinct species.
I n his 1901 book Our National Parks, early conservationist John Muir asserted that "wildness is a necessity". Environmental journalist George Monbiot agrees, but in Feral we discover just how challenging it can be to fulfil that need.

Monbiot starts by recounting his adventures during the 1980s gold rush in the Brazilian state of Roraima, among murderers, desperate miners and the Yanomami tribe's faith healers. Far from showing bravado, these tales reveal how negligence, inaction and greed have led to environmental devastation in the region. After six years, Monbiot returns home to Wales to find himself "living a life in which loading the dishwasher presented an interesting challenge". Burdened with angst, he looks to wilderness as an antidote to a descent into a "small and shuffling life".

But Monbiot finds that Wales has been tamed by forces

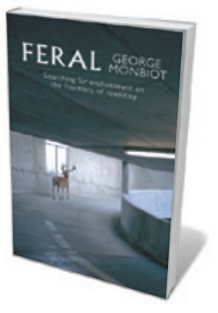

Feral: Searching for Enchantment on the Frontiers of Rewilding GEORGE MONBIOT Allen Lane: 2013. 336 pp. £20 similar to those that are devastating the Brazilian wilderness. He uses his home territory as a microcosm to explore 'rewilding' - the process of reintroducing locally extinct species - and elevates this from a paradigm in conservation science to a major environmental issue. He goes even further, envisioning rewilding as a way to revitalize imprisoned human sensibilities by restoring the endless source of delights, surprises, adventures and thrills that wilderness provides.

Rewilding seems simple: let jaguars roam the American West and rhinos repopulate the Nepalese-Indian border, or allow wolves, lynxes, wildcats, wolverines, beavers, boars and even moose to return to Wales. Yet Monbiot discovers that rewilding is not a straightforward process.

For a start, which species should be prioritized? Some were hunted to extinction not long ago - for example, boars in the thirteenth century. Others, such as moose and wolverines, disappeared thousands of years ago for unknown reasons. Should we go back to the Pleistocene epoch (which ended some 12,000 years ago) and use $\rightarrow$ NATURE.COM For more from Shahid Naeem on redefining the wild, see:

go.nature.com/pmrusq 